\title{
Women, race and assimilation: the canadianizing 1920s
}

During the 1920s the IODE was heavily involved with immigration and the canadianization of immigrants. Ideally, canadianization involved assimilating all immigrants into the Canadian mainstream of the time. As canadianization was based upon mimicking Britain as much as possible, British people were considered the easiest to canadianize. A special interest was displayed in British single women, who the IODE hoped might migrate to Canada and there become wives and mothers. Well aware of the importance of mothers in passing on culture, the IODE performed a considerable amount of maternal work with new immigrants. It was the IODE members' place to attempt assimilation in the homes of 'foreigners', this being considered 'women's work'. As female imperialists, they used techniques familiar to those of other patriotic organizations around the Empire, promoting the English language and an imperial curriculum at every opportunity. During the interwar years the IODE's preference for British immigration was strengthened through collaboration with both Canadian and British governments, attempting to overcome the contradictions between the policies of the two nations. To assimilate people of other than British origin, the IODE devoted increasing effort to its canadianization programme. For all involved with Canadian immigration, the 1920s started as a time of great hope and potential.

\section{Preference for 'British stock'}

The IODE was a firm supporter of the 1919 Canadian Immigration Act which, amending the Act of 1910, prohibited immigrants deemed unsuitable and made even clearer the immigrants' need to assimilate. During the interwar years the IODE frequently reiterated its preference for British immigration, forthrightly stating: 'The consensus of opinion 
regarding that important feature of our national life, immigration, is the fact that the IODE considers a selection policy should be pursued by the Government and that there should be a predominance of British Settlers. $^{1}$ The sacrifices of the First World War were used as a justification for preserving the predominance of Anglo-Celtic immigration, such as in a 1920 address in Manitoba in which Mrs C. C. Hearn of Brandon told the women's section of the Grain Growers' Convention: 'We sent our splendid men overseas to fight for us and for our country, and surely now ours is the great responsibility of preserving and building up from them the land for which they made such great and supreme sacrifices. ${ }^{2}$

Given its preference for British immigration, it is not surprising that the IODE supported the British Government in its postwar emigration plans for British people. After the First World War, the British State renewed its tradition of the settlement of British people overseas in British territories, especially in the 'white' Dominions of Canada, Australia, New Zealand and South Africa. ${ }^{3}$ State involvement centred around the 1922 Empire Settlement Act, which authorized assistance for passages and land settlement for fifteen years, with $£ 3$ million allocated each year. ${ }^{4}$

Gender was of vital concern in post-First World War British emigration to Canada, and it was here that the IODE focused its attention. The Empire Settlement Act was motivated by the perception that there was a surplus of women in Britain. Citing figures according to which women exceeded men in Britain by more than a million, Secretary of State for the Dominions Leo Amery argued that women from the 'centre of empire' were needed on the 'peripheries'. He proposed that salvation for redundant female workers in the stagnant postwar economy lay in the British colonies, where there was still an overabundance of men. ${ }^{5}$ The idea of 'redundant women' was not a result solely of First World War battlefield losses. The mythology had been popping up in Britain since the 1850s, and was associated not just with Britain's changing social dynamics but with the populating of the Empire. ${ }^{6}$

In addition to ridding Britain of its 'surplus' was the benefit of potential economic, strategic and cultural development of the dominions. ${ }^{7}$ In Canada, it was believed, there were vast expanses of land waiting to be populated with 'fresh British stock'. ${ }^{8}$ According to Bernard Semmel, writing in 1960, a social imperialist doctrine of the 1920s saw the open resources as an opportunity for economic development and a means of renewal for a British race polluted by industrial urbanization, all of which would serve to strengthen the Empire.' As Stephen Constantine so neatly sums it up: 
The claimed benefits of female migration were therefore essentially conservative: the confirmation of women's traditional roles and the satisfaction of masculine needs, the preservation of British cultural and political predominance in the dominions by the breeding of new generations from fresh British stock, and the sustaining of economic production and prosperity through the stimulus of more marriage, higher birth rates, population growth and larger markets. ${ }^{10}$

Despite an overall enthusiasm for British immigration to Canada, and its legislated preference for British immigrants, the Canadian Government was concerned that Canada was viewed in Britain as a 'dumping ground' for the unfit. ${ }^{11}$ Those Canadians who were themselves of the lower classes, such as trades unionists and veterans, were protective of their own interests and viewed immigration as an attempt to flood the labour market. ${ }^{12}$ In this tug of war, the IODE, sensitive to class distinctions, admitted that there could be 'absolutely worthless British immigrants' ${ }^{13}$ Thus, IODE National Education Secretary Constance Boulton of Toronto stated in an address on immigration:

I am convinced the foreign immigrant is as varied in quality and type as the British immigrant. We have magnificent British immigrants, and absolutely worthless British immigrants, and among those foreigners whom we call dirty, filthy and ignorant (I hear it on every hand), are you not sure among those immigrants there are magnificent types of men? The lower classes of foreigners in Europe have I venture to say a far greater appreciation of music and art. $^{14}$

Here, class concerns dampened the IODE's usual uncritical enthusiasm for Britishness, and there was a mystique attaching to European 'otherness', a bonding with an imagined form of culture.

Canada was particularly eager to attract male agriculturalists and female domestics. ${ }^{15}$ Considerable efforts were made to obtain British male agriculturalists. It was veterans of the First World War and their families who were offered the first passages to take up land in the British dominions under the Returned Servicemen's Scheme. ${ }^{16}$ Under the Empire Settlement Act, there were further special provisions for veterans to take up work on the land. ${ }^{17}$ Such attempts to get British settlers on to the land were not very successful. Of the 8,500 British harvesters who went to Canada, most returned and the scheme was called a failure. ${ }^{18}$ As Barbara Roberts's work on deportation at this time has shown, what was not publicized back in Britain was that those who did not live up to expectations would be sent back. ${ }^{19}$ There were not as many immigrants as were wanted by Canada, and the qualities of British immigrants were not always found satisfactory. 
Children were among those in Britain who were perceived as needing to escape from urban decay. As child migration continued under the Empire Settlement Act, between 1870 and 1930 Canada received more than 100,000 children. ${ }^{20}$ At the end of the First World War the number of British immigrants who had gone to Canada as children and who subsequently 'flocked to the colours in Canada during the war ${ }^{7}$ was used as evidence by government officials of the good citizenship promoted by the scheme. ${ }^{21}$ In the 1920s, however, the IODE began to question the scheme, raising doubts about the conditions for children. The IODE's criticisms of child migration were influenced both by its connections to the new welfare organizations and by the fact that the children were British and hence deserving of better treatment. At the 1924 IODE convention Charlotte Whitton, IODE member and director of the Canadian Council on Child Welfare, spoke:

Why are so many children being sought for placements in homes and on conditions which the Canadian authorities will not accept for our children? It does not redound to the credit of Canada that in an official publication of the Dominion Government we should speak of getting farm helpers from ten to thirteen years of age. Do not these facts bear out a contention of a cheap labour demand, a cheap labour that approaches perilously near a form of slavery? ${ }^{22}$

As a professional social worker, Whitton was critical of emigration agencies and their inspection processes, and of the guardianship of children. ${ }^{23}$ To treat British children as cheap labour made the scheme all the more distasteful. Later in the twentieth century, the IODE's criticisms of the scheme would become widely held. Joy Parr's work on child migration to Canada has revealed tales of suffering and abuse, as well as of happiness and success. ${ }^{24}$ Child migration to Australia extended to the 1950s and 1960s, and was the subject of a 1990s' inquiry by the British Government, as Alan Gill has documented. ${ }^{25}$

\section{'Surplus' British women}

The targeting of British domestics in the Empire Settlement Act appealed to both British and Canadian interests. While Britain held ambitions of lessening the surplus in its number of women, Canada hoped that an inflow of domestics would alleviate the shortage of domestic labour in Canada. Over 170,000 British women came to Canada between 1900 and 1930 declaring their intended occupation to be domestic service, about half arriving in the decade before the First World War and the rest in the 1920s. ${ }^{26}$ Marilyn Barber has looked to the motivations of those women who chose to emigrate: 
Women often have been portrayed as passive or adaptive in the emigration process, sharing the consequences of a move initiated by men. Yet in all periods, single women came to Canada, many as domestic servants, for reasons of individual or family betterment very similar to those motivating male immigrants. Those emigrating as domestics were young women of prime marriageable age. While some were very aware of improved chances for marriage in Canada, and others used domestic service as a way to join fiances who had emigrated, most domestics came primarily for economic reasons. $^{27}$

To the IODE, occupation was secondary to race and, with its preference for British immigrants, the IODE backed the British domestics. In encouraging this British immigration, the IODE moved across a number of spaces that transgressed constructed 'public' and 'private', as well as national, boundaries. The imperial context was an overriding framework. In its work, the IODE was but one actor among many interested parties who were also imperial in attitude and scope. Voluntary organizations such as the YWCA, the Salvation Army, the Girls' Friendly Society, the Oversea League and the Navy League were all hard at work to foster British migration.

During the 1920s immigration, especially of single women, was controlled by a complicated combination of state and voluntary interests. Increased government bureaucracy was attempting to manipulate, and replace, an extensive system of private philanthropic agencies and voluntary societies. While women's immigration gained importance through the Empire Settlement Act, the bureaucracies set up were still heavily dependent upon the voluntary work of women, and they often involved those women in their structures. The new Women's Division of the Department of Immigration, for example, sent staff officers to Britain to give final approval in the selection of British domestics. In Canada the division established a chain of women's hostels to receive parties of domestics, who were then placed by a new government employment service. ${ }^{28}$ These agencies took over tasks previously controlled by women's voluntary organizations. Women's voluntary work as the maternal care givers of a private domain was increasingly professionalized.

Increased state involvement led to multiple positionings for the IODE. The new bureaucracy involved collaboration between voluntary and state interests, and the IODE positioned itself in both arenas. An added benefit was that among the IODE membership were 'insiders', prominent members such as Charlotte Whitton and Margaret Grier who were part of Ottawa's new professional 'femocrats'. Femocrats were women who, thanks to the efforts of a first wave of feminism, had received higher education. By the 1920s they were employed by 
governmental and private organizations, largely in welfare work. Although not often overtly feminist, and while necessarily a part of the public sector, these women were well aware of their position, and gathered together for support and networking. For example, the Elizabeth Tudor Chapter, formed in Ottawa in 1929, drew its limited membership of thirty-five from women who were occupied in public welfare work, nursing, teaching and various branches of civil service. It was characterized by highly educated, unmarried, professional women, such as Charlotte Whitton and Margaret Grier. Among its many activities was organizing parties for the entertainment of women brought to Canada by the Women's Division of the Department of Immigration. ${ }^{29}$

Besides its well-placed members, the IODE was represented on Canadian boards such as the Canadian Council for the Immigration of Women (CCIW) that was made up of women's voluntary organizations and had been set up in 1919 as an advisory body to government. The CCIW's main concerns were to aid British women immigrants, either out of work after the war or generally disrupted by the war, and to set up a network upon their arrival in Canada, as Mariana Valverde puts it, 'to ensure that once in Canada the prospective domestic servants did not escape their fate and seek other kinds of work or relationships with men'. ${ }^{30}$ Extending the pre-Second World War hopes for female migrants, their protection and surveillance were increased by the provision of matrons on boats and trains, and eight hostels were set up across the country to provide single female immigrants with accommodation and supervision.

Ambitious plans were only partially fulfilled. Although it had grand professional intentions, the CCIW was dormant from 1922 until 1927. In 1927 the IODE, dismayed at the lack of coordination of the 119 organizations involved in immigration work, arranged a meeting between its president and the head of the Women's Immigration Department, Miss Mary Burnham. ${ }^{31}$ Ever ready to promote its objectives, the IODE thought that the Government should call together the CCIW and attempt better coordination in order to attract more female British immigrants. ${ }^{32}$ At the same time as it publicly expressed a desire to collaborate with other organizations, such as the Salvation Army, the IODE was weary of committing energy to those organizations' projects and demands, and attempted to concentrate its efforts. In 1928, caution was expressed before agreement was reached to participate in the Navy League's migration scheme. In considering whether to take on the welcoming and welfare of these families, Whitton pointed out that chapters throughout Canada were already doing such work, in particular for the YWCA in the Essex Peninsula and with the SOSBW. ${ }^{33}$ 
The IODE's connections and collaborations with state bureaucracies extended beyond Canada, encompassing imperial organizations. As part of its preference for 'British stock' the IODE was in close contact with agencies in Britain, especially the SOSBW. That organization was another example of an increasing state involvement in activities that were still gendered female and private, a tendency manifesting the State's still heavy reliance upon the voluntary work of women. The SOSBW was a part-voluntary, part-statal organization, whose goal was to increase the number of white British women throughout the Empire outside of Britain. Founded in 1919 by the amalgamation of the British Women's Emigration Association, the South African Colonization Society and the Colonial Intelligence League, in 1920 the SOSBW was recognized as the Women's Branch of the Oversea Settlement Department of the Colonial Office. Its provincial representatives, who were all voluntary workers, served on the local employment committees of the Ministry of Labour when women applicants for oversea settlement were interviewed. ${ }^{34}$ The interwar years marked a new era for those women who, bolstered by first-wave feminism, were able to exert an influence on official imperial matters, especially where they concerned other women. As Julia Bush argues, in the area of British female emigration, it was clubwomen and women bureaucrats who were able to exert such a considerable formal influence. ${ }^{35}$

Class continued to be an overt concern of the IODE. While it was supportive of domestic servants, the IODE continued to encourage the immigration of educated and middle-and upper-class women. In 1926, for example, the IODE's immigration committee articulated its conception of class in this way:

While the need for household workers in Canada is unlimited it is not desirable that Canadian stock should be replenished solely by that one class of British newcomer. Surely it is important that a certain number of women of education and training of various kinds should be encouraged to come to help populate our vast areas to be 'home-helps' in families in the more remote districts, or in whatever part such openings could be provided. The Government furnishes wonderful assistance and opportunity for the household workers, but for the daughters of professional men, for young women with possibly a little capital anxious to start out in life on their own, much less is done. Your committee feels that it is of the utmost importance that Canada should encourage to come to its shores women who will include among their numbers those of education and ability. ${ }^{36}$

It can be surmised that the IODE was not down-playing the unquenched demand for household workers, but rather was stressing the need to perpetuate class hierarchies. 
The IODE wanted to copy a British scheme for Australian settlement which, assisted by the Victoria League in Australia, encouraged educated women from Britain to settle there. The scheme involved an assisted passage for women aged 18-35 years, and a year of domestic employment at a fixed minimum salary in Victoria, while the women kept in touch with the Victoria League. In contrast to other domestic labourers, it was stated that an 'educated woman in the country districts will often find that she shares the work with the members of the household, and also takes part in their social life'. ${ }^{37}$ Such a scheme was considered to be an excellent opportunity for a small number of educated women who desired to go overseas and who were willing to take up domestic work under good conditions. The IODE found it appealing that educated British women might come and live in its communities, since such schemes would offer the 'greatest openings for the chapters to make a definite contribution to the strengthening of the ties which bind the women of the Empire together'.$^{38}$ Chapters were urged to study the potential openings in their own localities.

The imperial scale of immigration work involved recruiting from the imperial centre, Britain. Hence, the IODE sought closer contact with the SOSBW and British women's voluntary societies, and again considered the possibility of an office in London. In the words of its immigration convener, Mrs Graham Thompson, 'How much it would help the Order to keep in touch with the movements of imperial women in the Motherland to have its representatives there, with the SOSBW and tap potential British Immigrants at their source. ${ }^{39}$ During a trip to London Mrs Thompson met with Dame Meriel Talbot and Miss Franklin of the SOSBW, and with Lady Cowan of the British Women's Patriotic League. ${ }^{40}$ Once again, however, the IODE was a victim of the imperial structure that, ironically, it supported and even perpetuated. The Victoria League in London threatened to get nasty if the IODE opened an office there, making it clear that any activities which seemed like steps towards organization would be considered as an infringement of the understanding between the two societies. So the IODE backed down and concluded that it should continue to focus its efforts on Canada, 'making a tangible contribution at this time to the upbuilding of a British Canada ${ }^{\prime}{ }^{41}$ Here there was plenty for the IODE to be concerned about.

\section{From disappointment to articulating Anglo-Canadian identity}

For all of the efforts to encourage British immigration during the 1920s, it was a time of disappointment for those concerned. The demand for 
domestic servants and agriculturalists consistently exceeded supply. ${ }^{42}$ Marilyn Barber found that, 'because Canadian-born women preferred employment in factories or in the increasing number of offices and shops to domestic work, Ontario housewives increasingly turned to immigration to solve the servant problem' ${ }^{43}$ Once in Canada, however, British girls were not so different from those born in Canada in their aspirations, and did not stay long in domestic service. ${ }^{44}$ According to Janice Gothard, there was growing disenchantment among British women with the prospect of paid domestic labour. ${ }^{45}$ Of the approximately 100,000 single women assisted under the Empire Settlement Act, around 80,000 of whom went to Canada, few remained in domestic service. ${ }^{46}$

For the IODE, with its preference for British immigrants, the 1920s was a particularly disappointing decade, and that disappointment soon turned to a fear of the 'foreigners' who continued to emigrate to Canada. IODE immigration spokesperson Laura Thompson wrote in 1926:

Should we now not recognize that Canada's continuance as part of the British Empire may be imperiled by a failure to build up a population resolved to remain loyal to that Empire? Should we now allow ourselves to be timorous as to the possibility of Canada, this great country - being able to provide a livelihood for those British who are already in our midst ${ }^{47}$

Such an opinion was in line with more general beliefs of the time which, grounded in eugenics and fuelled by declining Anglo-Celtic fertility, in both Britain and Canada, combined to produce a fear of foreigners flooding in from less desirable parts of the world, swamping and destroying British institutions. ${ }^{48}$ According to Carrothers, a pro-British immigration academic writing at the time from Saskatchewan: 'it is this foreign-born population that constitutes the greatest problem in Canadian immigration'. ${ }^{49}$ An editorial in Echoes warned: 'In Canada today seven foreigners arrive for every five British born, and disturbing tales are told of the continental farm labourer who, because of his low standards of living, is willing to work for a pittance, thus displacing Britishers who cannot exist decently on such a wage ... [It] will be difficult for British traditions to survive. ${ }^{50}$

In this context of growing fears for the survival of an Anglo-Celtic population, it was an important time for the IODE to reassert its preference for 'British stock', forming its beliefs out of the fear of encroaching difference. A speaker at the 1928 National Meeting stated: 'Perhaps no subject before the public today is receiving greater attention of all thinking people than the problem of solving the populating of the 
great land areas of this vast Dominion.' In advancing the belief that Canada needed immigrants the opinion was voiced that it would 'be best for Canada to bring those of British stock, who would best carry on her traditions, who possessed of these requisites /willing hands and active brains), would not only add to the economic wealth but the social strength of our Dominion'. ${ }^{51}$ The assumption was that British migrants were superior to all others, mentally and physically. Furthermore, they would perpetuate Canadian 'traditions' deemed appropriate. In the face of the reality of heavy non-British immigration, the IODE undertook its efforts at canadianization.

Following the pattern established before the war, the IODE's first outreach continued to be the port welcomes, where help was immediately practical and maternal, providing rest rooms for women and food and drink for all in canteens. ${ }^{52}$ At Quebec, the largest port of immigrant reception, a postal booth was staffed, and their duties included the distribution of IODE notepaper. Good use was made of these services: in 1930 the postal booth was open for 185 ships and 13,892 letters were posted. ${ }^{53}$ As well as ports, train stations were important places where the IODE provided aid for arriving immigrants. In 1930 it was reported that at Bonaventure Station in Montreal, transfer point for the west, Montreal chapters met 171 trains and 25,954 newcomers passed through the rooms where the IODE retained a matron. ${ }^{54}$

In the welcoming work, too, boundaries between voluntary and statal organizations became blurred and the IODE began collaborating with many other societies, such as the Travellers' Aid Society and the Navy League. The IODE was attached to large projects like the Red Cross seaport nurseries in Saint John, Halifax and Quebec. The nurseries were run in cooperation with the Federal Department of Immigration and Colonization, and managed by the Red Cross. Echoes in 1927 reported that, in six years, 84,463 infants and children had been cared for at the nurseries, with the IODE's contribution including tea and biscuits for parents. ${ }^{55}$ This work depended upon many hours of volunteer labour.

Soon after the First World War the IODE realized that canadianization would be more influential if continued beyond the spaces of ports and stations. The IODE followed eugenic reasoning and urged intervention to improve and absorb the 'racial' qualities of future generations, both physically and mentally. This was particularly important in work with health services. The ease with which immigrants were considered to be successfully assimilated corresponded with the categories of the racial hierarchy. Anxiety was directed towards Asians and African Americans, who were considered unable to be readily assimilated, or canadianized. In 1923 provincial politicians in British 
Columbia successfully pressured the Canadian Federal Government to stop all Chinese immigration. ${ }^{56}$ The IODE's provincial chapter of British Columbia supported this move and urged its national executive to follow suit. A 1923 article on 'the Oriental problem' in Echoes stated: 'Eastern Canadians are beginning to realize that Orientals will not fuse in our melting pot . . . Let us, in all conscience, stand side by side with our fellow-citizens of British Columbia. ${ }^{57}$

Consistent with constructions of race, there were strong regional and ethnic differences in how immigrants were treated. Attitudes towards groups of migrants depended on how easily canadianized they were perceived to be. In Ontario and the east, where immigrants were largely British and Northern European, and in marked contrast to its support of bans on Asian immigrants, the IODE organized festive 'Christmas cheer ${ }^{\prime 58}$ According to a 1930 account, parties were given for $800-1,000$ girls in different parts of Ontario, 500 new settlers were guests at a 'monster picnic' in New Brunswick and sixty-four Scandinavian families received attention from chapters in New Brunswick. ${ }^{59}$

Although some classes of immigrant were deemed undesirable, looking on the pragmatic side the IODE recognized that it was not helpful to advocate 'wholesale denunciation of the foreigner in our midst', the majority of whom it considered to be industrious people 'doing their duty, as they know it, and filling a great need in the industrial life of our country'. ${ }^{60}$ The IODE focus therefore shifted to taking responsibility for the canadianizing of immigrants. Looking back to the pre-First World War years, a member in 1920 noted:

We did practically nothing. We paid them not nearly the attention that we should have paid to imported cattle. Did we try to understand their point of view, or make them understand ours? No. We made no effort to even teach them our language ... it is just lately that we awoke to the vital importance of educating their children to be Canadians ... If we expect any miracles to be performed among our foreign born, we have got to perform them ourselves. ${ }^{61}$

With such reflections, and with a new zest for intervention, the IODE set out to meet the challenges of canadianization.

Very importantly, through canadianization the IODE was forced to confront what 'Canadian' meant, to move beyond articulating what it was not to expressing just what it was to which immigrants were supposed to assimilate. The IODE was still at its most comfortable rattling off mutations of British rhetorics of God, monarch and Empire, and the associated sacred symbols; but increasingly, and because of the immigrant presence, instead of being centred on an imagined Britain, national identity began to locate itself within the space and the people of 
Canada. What Said has termed betweenness, 'overlapping and intertwined geographies of identity', ${ }^{62}$ becomes very apparent here, as definitions of 'Canada' were derived from Britain, but lived in Canada, and mingled with many other influences. Canadianization was initially constructed by the IODE in very practical terms, emphasizing skills such as fluency in the English language and good housekeeping. It was not until later in the century that the IODE was able to articulate a 'Canadian' identity. In the meantime, as a safe fall-back position, canadianization was constructed to consist in everything that the alien was perceived not to be.

To achieve canadianization, it was believed, immigrants must not be allowed to live in segregated spaces. A growing fear of the segregation of new Canadians was expressed in Echoes in 1919: 'In Manitoba about 50 per cent of the population is alien, and in the other Western Provinces the proportion is still higher. Is it any wonder, therefore, that she feels the gravity of the situation and the necessity of speedy action on the part of every loyal Canadian?' ${ }^{23}$ In a 1919 address titled 'Canadianize the Aliens' Mrs George H. Smith, national education secretary, presented a large chart of Saskatchewan, showing in coloured blocks the 'different nationalities, origins and numbers of each nationality represented in that Province ${ }^{64}$ Also with an awareness of the importance of space in the assimilation or otherwise of immigrants, in 1920 Ethel Craw argued the risk of spatial enclaves:

The industrial and agricultural development of Canada, the building of her railroads, and the working of her mines, require an ever increasing supply of unskilled labour from the over-populated countries of Europe and the Orient. But we must provide these toilers with something more than just work for their hands. We must not allow them to live apart in 'Little Russias' or 'Little Italys', never mingling more than is necessary with their Canadian neighbours, nor taking any interest in our national affairs, and cherishing the purpose of returning to their native land when they have saved enough money for their old age. ${ }^{65}$

Segregated spaces, it was argued, could lead to immigrants being 'tainted' with socialism, as Ethel Craw suggested was happening to Finns in Copper Cliff, Ontario. ${ }^{66}$ After the war, and mindful of the Bolshevik Revolution in Russia, there was a strong fear of 'red revolt'. ${ }^{67}$ Furthermore, there was fear that immigrants who lived in a block would vote as a block, thus posing a threat to the political system, a concern documented by Howard Palmer with respect to underprivileged immigrants of Central and Eastern European origin and Finnish immigrants living in urban centres and mining camps. ${ }^{68}$ In 1926 the president of the Order identified a complex non-British threat: 
As Daughters of the Empire and loyal Canadians, we should be alive to the serious situation that confronts us in the propaganda that, as the years advance, is being slowly and surely directed at the undermining of the British connection in this Dominion, and the disintegration of those stable elements that have placed Canada in its proud position ... I want to tell you that we have come to a dangerous position. The menace of Communistic and atheistic propaganda is also becoming widespread in every country. ${ }^{69}$

Connecting immigrants with Communism was much more than a fleeting concern, and it would surface again later in the century.

After the First World War, fluency in English was considered to be the most vital component in canadianization. An imperial education, that provided English-language skills and knowledge, was central to the construction of an Anglo-Canadian identity. An article in Echoes stated that immigrants must be trained in the 'high ideals' of citizenship. Immigrants should 'learn English, speak English, and think English'. Indeed, it was suggested that if immigrants could be persuaded to undertake 'this heroic method of learning English, nine-tenths of the Canadianizing problem would be solved' ${ }^{70}$ Plans for the canadianization of children extended far beyond English lessons. The IODE subscribed to a complete imperial curriculum that, to borrow from John Mangan, promoted the 'ruling discourse' and legitimized the superiority of its rule. $^{71}$ The IODE's national education secretary, Mrs George H. Smith, appealed in 1919 for an 'intensified and broadened Canadianization Campaign', the object of which was to 'banish the old-world point of view, old-world rivalries and suspicions, and make our foreign-born citizens all the way British, in language, thought, feeling and impulse' ${ }^{72}$ Not surprisingly, Smith advocated the teaching of the values of patriotism in the public schools, particularly in outlying districts.

But the IODE experienced difficulties in the instruction of 'patriotic ideals' among ethnic groups. During the 1920s, for example, the IODE questioned the determination of the Doukhobors in British Columbia to educate their children themselves, and resolved to copy schemes underway in Ford and Kitchener to arrange schooling for 'the foreigners in our midst' ${ }^{73}$ Ever aware of the power of segregation, the IODE perceived a threat from sects such as the Western Mennonites who, for religious reasons, attempted to educate their children separately from non-Mennonite children. In this connection the IODE referred to the 'menace to Canadian unity that may arise from the natural tendency of aliens to segregate in unassimilated groups' ${ }^{74}$

To the grand canadianization programme in schools across Canada the IODE contributed many vigorous and varied ideas: travelling libraries, children's newspapers and the distribution of copies of the 
British North America Act to schools and libraries. Prizes were offered for patriotic short stories and one-act plays. ${ }^{75}$ The War Memorial Scheme (the focus of chapter six) included a component providing patriotic pictures, lectures and libraries to 'foreign' schools. ${ }^{76}$ It was as a part of this canadianization scheme that in 1919 Constance Boulton went on a travelling 'illustrated lectures' tour, undertaken in collaboration with the Navy League of Canada. Boulton visited some thirty-five towns in western Ontario and delivered almost eighty lectures to approximately 30,000 children. She showed pictures of King George, a lion and little cubs to symbolize and naturalize the relationship between the British Empire and the British dominions, and of ships, 'the bulwark of our unity'. Boulton's images and stories were constructed from an imperial narrative firmly founded upon mimicking the imperial centre, Britain. Shifts were occurring, however, in that such imitation produced Canadian heroes like General Currie, and the lectures included tales of the bravery of Canadians and their 'brothers from across the seas'. $^{77}$

In its education programmes, the IODE targeted isolated areas with high percentages of immigrants. In Alberta, especially, it was considered necessary to arouse 'an interest in the British ideals and traditions, which are our common heritage as Canadian citizens, amongst the 60 other nationalities besides the basic racial stocks of British and French origin'. $^{78}$ In the face of the perceived immigrant threat, the IODE included French Canadians in its 'basic racial stocks'; a passive inclusion, as at the time French Canadians were not considered a direct challenge to Anglo-Canadian identity. None the less, it was more recognition than previously obtained. With the presence of increasing numbers of non-British European immigrants, French Canadians were realigned towards Anglo-Canadians.

The IODE saw that teachers were vital transmitters in the canadianizing of immigrant children in classrooms. It was not alone in that view. In the Prairie provinces, teachers were seen as important in canadianization by a variety of organizations such as the Red Cross and the YWCA. ${ }^{79}$ In the 1920s the Province of Alberta IODE held summer school courses in canadianization at the University of Alberta. It also awarded a prize of $\$ 150$, on the recommendation of the local inspector, to a teacher who had served two or more years in a 'foreign' settlement. Applicants were asked to write an essay of 1,000 words describing their methods of canadianization. ${ }^{80}$ A prizewinner working in a Ukrainian settlement articulated her concept of British Canada:

The problem of the foreigner is a great one; greater than we realize. In Alberta we have over 60000 Ukrainians who occupy, roughly speaking, a 
block of land 60 miles square. They have brought with them customs, morals and religions that are in many respects a century behind AngloSaxons [sic]. A Ukrainian missionary told me they had no traditions, or what we would call such. They had no King Arthur, or Saint George. The only tradition was oppression. ${ }^{81}$

Ukrainian culture is clearly portrayed as inferior to British culture. The icons mentioned were from British history, and were to be mimicked in Canada.

The potential of the film medium was recognized early on by the IODE. Initially, film substituted for the earlier patriotic entertainments such as musicals and pageants. ${ }^{82}$ The IODE brought in experts to advise them on how to use film. Film had the advantage of transcending language barriers. The editor of Echoes articulated that significance in 1930, writing that 'the motion picture carries a mutual message in a country where common speech is not an inheritance. Before the "movies" Russian and Scandinavian, Italian and Dutchman, Englishman and Frenchman may sit elbow to elbow and vibrate sympathetically, for all understand the language of images. ${ }^{83}$ From this perspective the IODE advanced the superior merits of British films and petitioned for their purchase and viewing. In 1926 an article in Echoes indicated its view in its title: 'British films to the front - getting the soul of England into pictures' ${ }^{84}$ Later, in 1945, in New Brunswick, the Princess Alexandra Chapter showed films about Canada and the royal family at two parties it gave for language students at vocational school. ${ }^{85}$

\section{Into the home}

The space of the home, as the place of immigrant women, was also an important focus of canadianization. To promote imperialism, nationalism and social purity, women were considered best able to exert their moralizing influence in the home. Perhaps it was an indication of their own feeling of maternal strength as women that the IODE recognized the importance of immigrant women in settlement, quoting the secretary of state for the dominions saying that 'pioneer wives are the Empire foundation stones', and themselves suggesting at the 1928 National Meeting that

[t]he new settler's success or failure in the new country depends to a great extent on the wife's attitude, whether she can rise above the first discouragements, through failure of the first crops, and other seeming obstacles, and adopt a more optimistic outlook; because we must remember that loneliness in that vast West has been a productive source of many failures in the life of a settler. ${ }^{86}$ 
Consistent with its 'racial' preferences, the IODE believed that British women could, with a little training, adapt to become strong and useful, while non-English-speaking women with different cultural values were dangerous. Because of their importance as mothers, such women were considered hostile obstacles to canadianization and were treated with more suspicion than were men. ${ }^{87}$ There were occasional voices of sympathy for the hardships that immigrant women faced, as in a 1919 article in Echoes that challenged the reader:

$[P]$ ut yourself in the place of the foreign-born mother - a stranger in a new land, husband and children learning the English language and Canadian ways and gradually growing away from the mother, a keen sense of unwelcome on the part of the native-born, forced by circumstances or the opposition of the native-born to live in unsatisfactory and un-Canadian surroundings. ${ }^{88}$

Other voices questioned whether such 'alien' women were worthy of being naturalized along with their husbands: 'Is she to have full Canadian citizenship because she is the wife or daughter of a naturalized alien, no matter whether she can speak our language or not, or is otherwise qualified?' The immigrant mother could be portrayed as the element most resistant to canadianization. In the words of the IODE's national citizenship and immigration officer, these immigrant women were primitive and 'apparently quite dominated by their men folk, and seem to us to have very little outlook for the future beyond a life of drudgery and repression'. ${ }^{89}$

To alleviate isolation and in the effort to canadianize immigrant women, the IODE was active in home visits, endeavouring actually to gain access to the home and to lead by example. In an article in Echoes, 'Reaching women in non-English districts', the suggestion was made:

Would it not be possible to place women community-workers in these thickly populated foreign districts where teachers' homes have been built by the Department of Education? The community workers could share the homes with the teachers, thus lifting some of the burdens off their shoulders. They would form community centres, visit the women and older girls in their homes, familiarize them with our language, gain their confidence, teach them elementary health conditions and how to care for the sick, and generally help them to adjust themselves to conditions in this country of their adoption. This would at least show the foreign-born woman that we, her Canadian sisters, are interested in her, and sympathize with her. And how far-reaching sympathy is, is it not? Its effect can never be measured. ${ }^{90}$

The article went on to suggest strategies for members to follow. The methods involved establishing, often on false pretences, 'sympathetic 
points of contact', such as through a 'friendly visit of one woman to another. Treat as if a native-born moving into neighbourhood. Find a sympathetic point of contact - a new baby, a sick child, some flower seeds, a pot of jam' in order to 'get her to help you and unconsciously you help her'. ${ }^{91}$ Even the teaching of English was invested with the ulterior motive of improving what was perceived to be the inadequate hygiene of immigrant homes, with the suggestion: 'Ask the women to bring their babies. While you are teaching the women get some tactful young woman who loves children to amuse the babies; perhaps wash them and turn them back to their mothers clean and happy. ${ }^{, 92}$ There was a strong perception that immigrants were living in unsanitary conditions. In the name of health and citizenship it was the job of the IODE to induct immigrant women within the cult of domesticity. ${ }^{93}$ It was suggested to members that they get doctors to help them in improving conditions and that members themselves 'try to improve the living conditions, but do it very tactfully. Sometimes a bouquet or a little picture will lead the foreign-born mother to tidy up a whole room. ${ }^{94}$

The standards the IODE applied in rural areas reflected the urban aspirations of its members, and were often based on theories far removed from the realities of lived experience. ${ }^{95}$ In rural areas the harsh position of women immigrants contrasted with the lives and position of urban and conservative members of the IODE. These were women who had the time to read influential advocate of women's rights Janey Canuck's article on the place of women in Canadian citizenship. Janey Canuck wrote in Echoes that 'women are interested in small parks, child-labour, the bettering of conditions in shops and factories, and juvenile courts' ${ }^{96}$ According to the article, women's place in such urban public spaces was from the 'standpoint of the home', while man's place was 'from the industrial side ${ }^{\prime .97}$ Hence, it was the citizenly duty of women to be active in promoting citizenship.

It was with a great sense of citizenly mission that the IODE attempted to influence immigration, and the subsequent life of immigrants. It did so in the places to which it could negotiate access, through its gendered, race and class identities. These were spaces considered by the IODE as dangerous and threatening. For much of the 1920s canadianization was constructed out of British-centred values, imposing an imperial narrative on the space of Canada. Increasing numbers of non-British immigrants, however, demanded that canadianization define more clearly what it meant to be situated in Canadian space. With an imperial narrative still strong, the IODE's response was pragmatic gendered work with immigrants, emphasizing skills above rhetoric. This was also because, with racial prejudices 
running high, there was scepticism about how successful canadianization could be, and it was still hoped that immigrants would be British.

\section{Notes}

1 NLC, IODE Year Book 1925, 30.

2 Echoes, 80 (March 1920), 33.

3 See Stephen Constantine (ed.) Emigrants and Empire: British Settlement in the Dominions Between the Wars (Manchester: Manchester University Press, 1990).

4 Constantine, Emigrants and Empire, 4: the Empire Settlement Act of 1922 was 'an Act to make better provision for furthering British settlement in His Majesty's Oversea Dominions'.

5 Dane Kennedy, 'Empire migration in post-war reconstruction: the role of the Oversea Settlement Committee, 1919-1922', Albion, 20: 3 (1988), 403-19, 407.

6 See Una Monk, New Horizons: A Hundred Years of Women's Migration (London: HMSO, 1963).

7 Brian L. Blakeley, 'The Society for the Oversea Settlement of British Women and the problems of Empire settlement, 1917-1936', Albion, 20: 3 (1988), 421-44, at 415.

8 Kennedy, 'Empire and migration', 415.

9 Bernard Semmel, Imperialism and Social Reform: English Social-Imperialist Thought, 1895-1914 (Cambridge, MA: Harvard University Press, 1960). Semmel shows the importance of geographer Halford MacKinder in such views.

10 Constantine, Emigrants and Empire, 8.

11 John A. Schultz, "'Leaven for the lump": Canada and Empire settlement, 1918-1939', in Constantine, Emigrants and Empire, 150-73, at 150.

12 Kennedy, 'Empire and migration', 416.

13 NAC MG28 I 17, 11, 5,37, Address by Miss Constance Boulton of Toronto on immigration work.

14 Ibid.

15 There is a large literature on female domestics. For an overview see Marilyn Barber, Immigrant Domestic Servants in Canada, Canada's Ethnic Groups, Booklet No. 16, (Ottawa: Canadian Historical Association with the Government of Canada's Multicultural Programme, 1991).

16 See Kent Fedorowich, Unfit for Heroes: Reconstruction and Soldier Settlement in the Empire Between the Wars (Manchester: Manchester University Press, 1995).

17 G. F. Plant, Oversea Settlement: Migration from the United Kingdom to the Dominions (London: Oxford University Press, 1951).

18 Schultz, "Leaven for the lump"”, 164.

19 Barbara Roberts, "Shovelling out the mutinous": political deportation from Canada before 1936', Labour He Travail, 18: fall (1986), 77-110; Whence They Came: Deportation from Canada, 1900-1935 (Ottawa: University of Ottawa Press, 1988).

20 Gillian Wagner, Children of the Empire (London: Weidenfeld \& Nicolson, 1982), xi.

21 Echoes, 79 (December 1919), 23. So says Mr Smart, chief inspector of British immigrant children under the Department of the Interior.

22 NAC MG28 I 17, 12, 2, 4, 225.

23 Ibid.

24 Joy Parr, Labouring Children: British Apprentices to Canada, 1869-1924 (London: Croom Helm; Montreal and Kingston: McGill-Queen's University Press, 1981).

25 Alan Gill, Orphans of the Empire (Sydney, New York and Toronto: Vintage, 1998).

26 Marilyn Barber, 'Sunny Ontario for British girls, 1900-30', in Jean Burnet (ed.), Looking into My Sister's Eyes: An Exploration in Women's History (Toronto: 
Multicultural History Society of Ontario, 1986), 55-73, at 56.

27 Barber, Immigrant Domestic Servants in Canada, 25. For a discussion of the women who migrated to Southern Africa at this time see Cecillie Swaisland, Servants and Gentlewomen to the Golden Land: The Emigration of Single Women from Britain to Southern Africa (Pietermaritzburg: University of Natal Press, 1993). For those who migrated to New Zealand, see Katie Pickles, 'Empire settlement and single British women as New Zealand domestic servants during the 1920s', New Zealand Journal of History, 35: 1 (2001), 22-44.

28 Barber, 'Sunny Ontario for British girls', 61, and Marilyn Barber, 'The women Ontario welcomed: immigrant domestics for Ontario homes, 1870-1930', in Alison Prentice and Susan Mann Trofimenkoff (eds), The Neglected Majority: Essays in Canadian Women's History, vol 2 (Toronto: McClelland \& Stewart, 1985), 102-21.

29 LPSC, IODE, The Ottawa Souvenir (Elizabeth Tudor Chapter IODE, 1935), 51.

30 Mariana Valverde, The Age of Light, Soap, and Water: Moral Reform in English Canada, 1885-1925 (Toronto: McClelland \& Stewart, 1991), 127.

31 NAC MG28 I 17, 4 April, 1927, Report of president's meeting with Burnham.

32 Ibid.

33 NAC MG28 I 17, 4 July, 1928, 154-5, Montreal, Quebec, Manitoba and Alberta have already accepted heavy responsibilities for their present immigration work.

34 Plant, Oversea Settlement, 78-80; NAC A-1054 MG28 I 336, SOSBW 2nd Annual Report, 1921, 2. In 1962 the SOSBW became the Women's Migration and Overseas Appointment Society, ceasing operations in 1963.

35 Julia Bush, "The right sort of woman": female emigrators and the emigration to the British Empire, 1890-1910', Women's History Review, 3: 3 (1994), 385-409.

36 NAC MG28 I 17, 4, 2, 8 September 1926, 121.

37 Ibid., 122.

38 Ibid.

39 Ibid.

40 Ibid., 120.

41 Ibid.

42 Marilyn Barber, 'Sunny Ontario for British girls', 56.

43 Ibid.

44 Ibid.

45 Janice Gothard, "The healthy wholesome British domestic girl": single female migration and the Empire Settlement Act, 1922-1930', in Constantine, Emigrants and Empire, 72-95, at 73.

46 Ibid., 73.

47 Echoes (1926-28), 9.

48 See Angus MacLaren, Our Own Master Race: Eugenics in Canada 1885-1945 (Toronto: McClelland \& Stewart, 1990), 29; and Susan E. Wurtele, 'Assimilation through domestic transformation: Saskatchewan's Masonic Scholarship Project, 192223', The Canadian Geographer, 38: 2 (1994), 122-33.

49 W. A. Carrothers, Emigration from the British Isles: With Special Reference to the Development of the Oversea Dominions (London: P .S. King \& Son, 1929), 246.

50 Editorial, Echoes, 109 (October 1927), 5.

51 NAC MG28 I 17 12, 1, 5, 1928 Annual National Meeting.

52 NLC, IODE 1900-1925, 31.

53 Echoes, 120 (October 1930), 8.

$54 \mathrm{Ibid}$. As a result of the voluntary labour of members at the IODE's rooms only $\$ 22.00$ was spent on any emergency relief for this large group.

55 Echoes, 107 (March 1927), 25: 'What the Seaport Nurseries are doing for Canada and new Canadians'.

56 Howard Palmer, Ethnicity and Politics in Canada since Confederation, Canada's 
Ethnic Groups Booklet No. 17 (Ottawa: Canadian Historical Association with the Government of Canada's Multiculturalism Programme, 1991), 11.

57 O. C. Pease. 'The problem of immigration', Echoes, 93 (June 1923), 16.

58 Charlotte Whitton, 'Report of the immigration committee', Echoes, 120 (October 1930), 9.

59 Ibid.

60 Ethel D. Craw, 'Is naturalization the remedy?', Echoes, 82 (October 1920), 44.

61 Ibid.

62 Said, Culture and Imperialism, 72.

63 Mrs C. C. Hearn of Brandon, Manitoba, 'Canadianization is vital question. Delay and neglect is dangerous - Must extend definite aid to aliens in our midst - Are alien women to have full Canadian citizenship?', Echoes, 78 (October 1919), 49.

64 Ibid.

65 Craw, 'Is naturalization the remedy?', 44.

66 Ibid., 44-5. Bolshevism was reported as spreading among workers in lumber and mining and railroad construction camps.

67 Daniel Francis, National Dreams: Myth, Memory and Canadian History (Vancouver: Arsenal Press, 1997), 36.

68 Howard Palmer (ed.), Immigration and the Rise of Multiculturalism (Vancouver, Calgary, Toronto and Montreal: Copp Clark Publishing, 1975), 3.

69 NAC MG28 I 17, 12, 1, 11, 'Insidious propaganda', Minutes of 1926 National Meeting at Admiral Beaty Hotel, Saint John, New Brunswick.

70 'Making Canadian subjects of our foreign population', Echoes (December 1919), 79.

71 J. A. Mangan (ed.), The Imperial Curriculum: Racial Images and Education in the British Colonial Experience (London and New York: Routledge, 1993), 6. Chapter four examines the construction of the imperial curriculum.

72 Echoes, 76 (March 1919), 31-3. Mrs George H. Smith spoke on 5 February to the Toronto Municipal Chapter.

73 BCARS N/I/IM 7P IODE. Provincial Chapter of British Columbia Minutes 1924. Summary of the 12th Annual Meeting British Columbia Provincial Chapter IODE, 23 and 24 April 1925.

74 Ibid.

75 NAC MG28 I 17, 3, 1 June, 1925, Suggestions for expansion in the National Educational Department.

76 NAC MG28 I 17, 3, 5 March 1919, The War Memorial scheme.

77 Constance R. Boulton, 'Teaching our children citizenship. Educational work being carried on by IODE bids fair to become one of the most important activities of the Order - What is being accomplished through medium of illustrated lectures', Echoes, 76 (March 1919) 55-7. This piece mentions the War Memorial Scholarships and lectureships, selected libraries, and pictures of a patriotic and national character that are to be placed in the 'foreign' schools.

78 'Canadianization work in Alberta', Echoes, 115 (March 1929), 7.

79 Wurtele, 1994.

80 Echoes, 120 (October 1930).

81 'Canadianization work in Alberta', Echoes, 115 (March 1929), 7.

82 See John M. MacKenzie, Propaganda and Empire (Manchester: Manchester University Press, 1984), especially chapter three, 'The Cinema, radio and the Empire'. At the January Manitoba Provincial Chapter meeting in 1921 Mrs Valance Patriarche of the Manitoba Censor Board gave an address entitled 'The influence of the motion picture on national life'. Ten years later Raymond Peck, director of Motion Pictures, Department of Trade and Commerce, Ottawa, provided the information for an article in Echoes headed 'The educational scope and possibilities of motion pictures'.

83 Echoes, 120 (October 1930), 39. 


\section{FEMALE IMPERIALISM AND NATIONAL IDENTITY}

84 Article by William T. Biesel, Echoes, 103 (March 1926), 10.

85 PANB MC 200 MS 45/2.

86 NAC MG28 I 17, 12, 1, 5, 13.

87 Ibid.

88 'What a woman can do in canadianization. A few suggestions for personal service Neighbourliness the keynote - Teach English - Other ways and means of helping along this great work', Echoes, 79 (December 1919), 35.

89 Ibid.

90 Ibid.

91 Ibid.

92 Ibid.

93 McClintock, Imperial Leather.

94 Echoes, 79 (December 1919), 21.

95 For a discussion of such contradictions in views of motherhood in Quebec, see Andree Levesque, Making and Breaking the Rules: Women in Quebec, 1919-1939 (Toronto: McClelland \&. Stewart, 1994).

96 Mrs Arthur Murphy (Janey Canuck), 'Canadian citizenship', Echoes 78 (1919), 53.

97 Ibid. 